\title{
Young Boys Learning to Fear, Hate and Harm: A Recipe for Sustaining Tribal Political Violence in Jamaica's Garrisons $^{1}$
}

\author{
Herbert Gayle
}

\begin{abstract}
This article is part of a larger report, 'Young Birds that Know Storm: Life Experiences of Boys of Ages 6-8 Years Living in Communities of Extreme Poverty and Violence'. Data from life histories of Jamaican inner city boys aged $6-8$ suggest there is a deliberate attempt by politicians and some community members and parents to encourage boys to fear, hate and harm people who support the rival political party. The closer the boys lived to the headquarters of political gangs or garrisons, the more likely they were to have a close relationship with the MPs, councillors and political activists who oversee the 'corners' of the communities, and the more violent their behaviour, suggesting that training in political tribalism affects the boys' relationship with their peers. Only boys who received a high level of nurture and supervision seemed to absorb little of the training to harm supporters of the opposing party.
\end{abstract}

\section{Brief background}

Jamaica's primary social problem is violence, specifically at the community level. Since 2005, when Jamaica recorded homicide rates of 64 per 100,000 , the country has been ranked among the most violent places on earth (data from Interpol 2006). Social violence in Jamaica is an urban phenomenon but is beginning to visibly affect rural communities as well. The vast majority of social violence in Jamaica occurs in communities described by Chevannes and Gayle (1998) as average and extreme inner cities or garrisons. Information on 'Special Communities' available in the national censuses allows us to estimate that these violent inner city communities make up about 20 per cent of the Kingston

Metropolitan Region (KMR). ${ }^{2}$ Data from the National Intelligence Bureau (2006) show that the KMR and other urban centres consistently account for over 80 per cent of homicides in Jamaica since 2000. Most homicides committed in Jamaica are the result of gang feuding involving young men. Males account for over 80 per cent of all admissions for violence-related injuries, and over two-thirds are under the age of
30 (Jamaica Injury Surveillance System: Injury Report 2005).

Jamaica's two main political parties that emerged out of its period of transition from colony to independent state operate within a frame of violence like two large gangs. This may seem surprising for two main reasons. First, on paper Jamaica boasts a comparatively great democracy. According to Mills (1997: 1-2), Jamaica is one of the few developing countries on the periphery of the industrial world that have consolidated a genuine competitive party system under the Westminster model of parliamentary democracy, based on identifiable interest that allows the political system to be open. ${ }^{3}$ Second, Jamaica's transition from colony to independent state seemed well planned and was relatively peaceful (Stone 1985: 20). The change took place incrementally over a long period. Nonetheless, what is often not emphasised is that Jamaica became a segmentary factional society very rapidly towards the end of the process of transition.

IDS Bulletin Volume 40 Number 1 January 2009 (c) 2009 The Author(s). Journal compilation (C) Institute of Development Studies Published by Blackwell Publishing Ltd, 9600 Garsington Road, Oxford OX4 2DQ, UK and 350 Main Street, Malden, MA 02148, USA 
Factional societies often develop when countries change from colonies to independent states. ${ }^{4} \mathrm{~A}$ segmentary structure is one in which political allegiances are based on forms of client-patron relations, to the effect that loyalty to a political party or community or turf supersedes loyalty to the state. Jamaica had its first general election in 1944. At this point, though Jamaica was not independent, the local middle class was allowed by the British planter class to campaign and almost completely run the election. The local founding fathers of Jamaica very quickly created a segmentary factional political system to guarantee the votes of the then illiterate masses. The two political parties, the People's National Party (PNP) and the Jamaica Labour Party (JLP), were formed during the 1930s and 1940s. By the second general election (1949), violence was obvious as party supporters tried to claim turfs. By the $1960 \mathrm{~s}$ both parties began constructing garrisons to increase their control over their core supporters. Violence became most severe in these garrisons of pooled votes. About a third of all the inner city communities of the KMR are garrisons to varying degrees. A garrison community is created by the development of large-scale housing schemes where houses are allocated to supporters of the political party in power; and the homogenisation by the dominant party activists pushes out the minority and guards against invasion from outside. In return for guaranteed votes, politicians allow supporters to pay no rent or utilities, and many kill to preserve this 'free-living'. A hard-core garrison community exhibits an element of autonomy; it is a state within a state. In such communities disputes are settled, matters tried and offenders sentenced and punished without reference to the Jamaican state. The Jamaican state has no authority or power, except in as far as its police and military forces are able to invade to enforce order (Ministry of National Security 1997). Police invasions can prove disastrous. In July 2001, 25 civilians and two members of the security forces were killed when the latter attempted to invade the garrison community of Tivoli Gardens in West Kingston. This caused national and international appeals to address how these communities are policed (Amnesty International 2001).

\section{Problems in the socialisation and nurture of boys}

As a child grows he or she is taught directly and indirectly through socialisation. According to
Evans and Davies (1997), socialisation refers to the process whereby an individual learns the skills, attitudes, values and dispositions to function competently in a particular society. Socialisation is simply the training of a person to adhere to the rules and norms of a society or community, in order that he or she can survive and make a contribution to the reproduction of that group. In violent communities, children are raised to survive violence. In this setting some children are taught to be violent in order to survive and/or are exposed to immense violence, while others are taught how to avoid violence and/or are shielded from experiencing it by parents and other community service providers and social units. Children learn through a variety of ways: observation, imitation, coercion, persuasion, reward, punishment, instruction and example (Chevannes 2001). Socialisation starts in infancy. The main agent of socialisation in a child's life is his or her family. Males and females are expected to act and behave differently depending on local rules. Boys begin to observe how other males act around them and mimic their actions. This is then reinforced by rewards or punishment given to them from socialising agents. If they correctly mimic the actions, they will most likely be rewarded with the approval to continue. Nonetheless, if they portray the wrong action they are penalised. The male is taught to be independent, self-reliant and hardened to obstacles he may face in pursuit of providing for his family. The family instils these values in him by giving him more freedom to roam than a girl child and by severely punishing him if he shows the slightest sign of being weak. Brown and Chevannes (1998) describe this as 'loosing the bull but tying the heifer'. Punishment for wrongdoing is more severe and he is quite often neglected emotionally and physically. He is not often hugged and is not encouraged to seek support when he feels depressed or unwell or else he will be seen as less of a man. In the Gender Socialization Project of the 1990s (see Chevannes 2001), we found that inner city boys were often left hungry while the girls were cared for. The boys were expected to hunt their own food or hustle at a very young age - even below the age of ten - as this was to prepare them for manhood and survival in the hostile inner city.

UNICEF's (UNICEF and STATIN 2007) situation analysis on gender disparities shows that boys in Jamaica are neglected as early as infancy by their 
parents. In its report, UNICEF refers to a national survey, the Multi-indicator Cluster Survey (MICS), ${ }^{5}$ which shows that 50 per cent fewer boys than girls are breastfed in Jamaica. The report also states that parents are more likely to take their girl children to seek high-quality healthcare than their boys. When boys do receive healthcare their parents tend to use public clinics and cheap medical facilities while girls are taken to private facilities. As a result, boys are more likely than girls to die from treatable diseases (see Manning 2008). Chevannes (1999) and later Gayle et al. (2004) found that in homes where resources are scarce the boy child is often sacrificed in order for the girl to experience further development. Chevannes (1999) argues that a boy is also the first to suffer deprivation where children are exposed. If resources do not allow for the children to attend school at the same time, girls are given the advantage over boys. Boys are then expected to earn and even provide for the girls' further development, concurrently stunting their own. Boys' suffering is often considered a means of producing hardened men who know how to survive. As Chevannes (1999) points out, such hardships make boys vulnerable to violence, given that they often compete violently for scarce resources, and they can be easily mobilised by gangs.

Secondary agents that children interact with outside of family, such as community people, institutions, peer groups, schools or the media, also influence adherence to the norms and values of a society. The impact of secondary agents increases dramatically when children enter school aged six. The problematic socialisation of Jamaican boys does not change when they enter the school system. Their peers revere boys who are tough, independent and are able to earn an income, while boys who act and behave in what is described as 'the mannerisms of a female' are ridiculed and even physically harmed. In the school the idea of toughening up boys is perpetuated by many teachers. As Evans (1999) found, boys have different experiences from girls in the Jamaican school system. Many schools discriminate against boys in a number of ways, including in teacher-student interaction, gender stereotyping of behaviour, academic expectation, corporal punishment, curriculum design and methods of teaching. Consequently, boys receive less attention academically and emotionally than girls from their teachers. Boys are also more severely punished in schools. Teachers have been found to flog boys but speak to girls in response to the same behavioural problem.

\section{Methodological note}

The formation of child protection structures in the Caribbean region is in a stage of infancy. Only recently, after years of appeals by local and international children rights groups, did the Jamaican Government establish the Child Care and Protection Act (2004), and set up an office of Children's Advocate to enforce the protection of children. This research, funded by Caribbean Child Support Initiative, is intended to provide data that can be used to encourage change in the area of child protection. The study is designed to examine the family and community life experiences of boys aged 6-8 years within garrison communities, characterised by high levels of poverty and violence. The rationale for choosing boys is clear. Studies show that boys are far more exposed to violence than girls. Males are at least four times more likely to kill or be killed than females in Jamaica (Ministry of Health 2002). In some of the garrison communities involved in this study one in nine males will not live to see age 40 . The developmental period of 6-8 years is very critical in a boy's life. According to Erik Erikson (1968) this is the early part of the stage called the school age. During this formative stage, parents are no longer the complete authority on any subject. Boys at this age increasingly depend on school and neighbourhood for guidance and reassurance. Peers and older boys become critical to their formation of identity and self-esteem. In other words they can be recruited or influenced towards acting violently. It is, therefore, not surprising that Gayle et al. (2004) found that a number of inner city boys began having sexual intercourse and participated in gang violence before age ten.

The boys were divided into three main groups: aggressive/violent, moderately aggressive/ moderately violent, and non-aggressive/nonviolent. The term Aggressive/violent $(A)$ is used to describe boys who have a history of violence. They have been observed over a period of time by their teachers and guidance counsellor to display aggression or violence towards other children. In interviews they also acknowledged carrying out acts of violence against others including:

- Instigating fights constantly

- Intentional wounding such as stabbing, 
throwing stones and bottles and hurting or 'drawing blood', or carrying lethal weapons on their person

- Using a gun with the intent to harm others

- Using the body: punching and pinching until the victim is harmed or skin is broken.

They also expressed a liking for fighting and harming others and expressed a reason to continue doing so.

Moderately aggressive (MA) is used to describe boys who retaliate or defend themselves if provoked, rather than immediately seek assistance from persons of authority. This group of boys has no history of extreme violence or initiating fights. They have been involved only in fist fights or other encounters that involve minor injuries only. Some of these boys have a history of using swear words a lot when provoked in order to repel attackers.

Non-aggressive (NA) is used to describe boys whose first choice is to report incidence of provocation to a teacher, parent or other adults. In most cases they will retreat if attacked. It may include isolated cases of fights when inevitable, when there is no one (especially adults) to turn to for help. In this group there are no repeat retaliations.

The site was a single primary school located in one of the many garrisons of the Kingston Metropolitan Region. About 20 per cent of the children benefit from the government's welfare service known as PATH (Programme for Advancement through Health and Education), which provides children with a cooked meal each day at school. The sample was composed of seven boys aged six years (13 per cent); 28 aged seven years (53 per cent) and 18 aged eight years (34 per cent). The technique used to collect the data from the boys is commonly called animated life histories. A team of seven trained interviewers used an eight-page standardised mixed method instrument to collect data on the lives of the 53 boys studied. The tool included a triangulation of four main activities:

- Fast drawing. The boys were given five minutes to draw the members of their families. From these stick persons, we learnt about family forms, relationships, employment status of family members and problems that exist within the households.
- Pictographic matrix. They were used to discuss power structures, relationships and support systems in the community that affect the boys' lives.

- Videographic analysis. Fourteen video clips were made, covering different issues in the lives of these boys. Among the issues addressed were happiness, sadness, hunger, playing, police-youth relations, 'informing' in the community (providing police officers or outsiders with information), hustling on the street, attending church and spending time with parents. No sound accompanied the video clips. The boys were asked to tell what was happening in the movies and to then say whether they had had similar experience in their lives. No act of violence was shown. The clips were expertly edited to suggest moods and actions that are not always explicit. Cartoons were used in most instances.

- Puppetry. Four puppets were used: one represented a fighter and another represented a male with a gun; of the remaining two puppets one displayed the colour orange and the other green. These were used to prompt a discussion of political tribalism. The boys were asked to say what they thought each puppet represented and were given five seconds to comment on the meaning of the colours (note that the colour orange is normally associated with the current opposition party, the PNP, and the colour green is associated with the ruling political party, the JLP).

\section{Political tribalism: learning to fear, hate and harm}

The boys came from 11 violent garrisons and five near-poor communities. Seven of the garrisons support one political party and the other four support the rival political party. All 11 garrison communities are located within a radius of two miles of the selected primary school. All the garrison communities experience constant police and joint military strikes due to the operation of four medium- to large-sized drug/political gangs and six smaller corner gangs and rival corner crews. Not surprisingly, the homicide rates for these communities exceed 100 per 100,000. All the boys who reside in these garrison communities have either seen a dead body or heard of a neighbour being killed by gunmen, political rivals or rival gangs, or by the police. 
Some have even lost relatives and close friends to violence.

Each of the five near-poor communities is aligned politically or otherwise to one or more of the 11 garrisons. People also move back and forth between these communities because of blood relations. Many of the near-poor population came from the neighbouring garrisons. For this and other reasons, the voting patterns of these near-poor communities closely mirror that of their garrison neighbours, though the former have some degree of political freedom that is absent in the garrisons. Four of the five near-poor communities are divided into JLP and PNP factions. Only one community has supporters of the JLP and PNP living harmoniously. The critical differences between the 11 garrison communities and the better-off near-poor neighbours are that the latter have a large proportion of employed people living in well-developed two- to three-bedroom concrete structures with proper sanitation, utilities that they pay for, paved roads, landline telephones and social infrastructure. In the neighbouring garrisons, people do not pay for utilities. This is one of the material benefits garrison members receive for their lifelong loyalty to the politicians in this client-patron system. These garrisons manifest obvious squalor. A minority of the houses here are comparable in size to the nearpoor structures. A few houses stand out like plantation mansions surrounded by slave quarters. These well-built and furnished houses belong to drug dons and political activists who oversee the garrisons. The most important social institutions in garrisons are the political parties and the gangs, unlike rural and other workingclass communities, which have several active civil and social groups. The problem with garrisons is that non-governmental organisations (NGOs) pull out when wars break out, leaving them socially isolated (Chevannes and Gayle 1998). Garrison leaders are the governing executive of the gang, local councillors and the Member of Parliament (MP) who controls much of the social action.

It is possible to shield boys from violence in the near-poor housing schemes that border the garrisons, though these boys are best friends with and relatives of those of the garrisons. The boys of the garrisons live in violence every day in varying degrees, almost without choice.

\subsection{The factor of proximity to the headquarters of a garrison}

If we agree with the position that the greater the garrison characteristics of a community the more problematic the environment is for raising a boy then we need to categorise the communities based on degrees of 'garrisonisation'. The data collected suggested six clear categories:

- Political gang headquarters (Zone 1)

- Heart of garrison (Zone 2)

- Affiliated small garrisons attached to larger ones (Zone 3)

- Political enclave (Zone 4)

- Garrison periphery (Zone 5)

- Near-poor affiliates (Zone 6).

The political gang headquarters and the heart of the garrison are the most dangerous zones for boys to be found in. The headquarters of a garrison is the most fortified. Due to its heavy arsenal it is difficult for the police and rival gangs to attack it. This does not mean it is always safe. The headquarters must brace itself for war. It is threatened by large joint military-police attacks and joint gang attacks. Attackers are all aware that they need to be strong to attack the fort. The section described as the heart of the garrison is the section that often protects the headquarters or (in some cases) attacks the headquarters to overthrow its executive. The affiliated smaller garrisons and the political enclaves are located farther away from a headquarters. The affiliated small garrisons are always vulnerable to attacks from opposing garrisons as they are not very close to the 'mother garrison'. In the area of study, the small affiliated garrisons are almost a mile from the centre. Political enclaves are small communities that support the party or gangs that oppose the large powerful political gang that controls an area. Life in an enclave requires constant 'sleep and mark time', says a community leader. Children are socialised to hide their area of residence from strangers as they cannot tell if they will be attacked. Living close to the enemy is dangerous. The residents cannot tell when they will experience an attack. Quite often the larger opposing garrison simply moves in and aggressively annexes the enclave. The garrison periphery and the near-poor affiliates are located farthest away from a headquarters and are the safest. Quite often the boys here are not controlled by the dons or 
Table 1 Geosocial political location and relationship with political agents

\begin{tabular}{lll}
\hline $\begin{array}{l}\text { Geopolitical } \\
\text { categories }\end{array}$ & $\begin{array}{l}\text { Quality of relationship with } \\
\text { political agents } \\
\text { Close }\end{array}$ & \begin{tabular}{l} 
Very deep \\
\hline 1 Gang HQ
\end{tabular} \\
\hline 2 Heart & 10 & 3 \\
3 Affiliate & 0 & 1 \\
4 Enclave & 0 & 0 \\
5 Periphery & 0 & 1 \\
6 Near poor & 0 & 0 \\
Total & 12 & 1 \\
\hline
\end{tabular}

politicians and parents are allowed to exert some degree of control over their sons. Unfortunately these boys interact with those from the core of the garrison and violence is contagious.

\subsection{Tribal political socialisation}

There are several findings that need to be highlighted here. The first observation is that the closer the boys lived to the headquarters of political gangs or the garrison the more likely they were to have a direct and close relationship with the MP, the councillor and the political activists that oversee the 'corners' of the communities. This can be seen in the data in Table 1. Of the 53 boys studied, 18 (34 per cent) noted that they had a close or very close relationship with a political agent. Notice that the vast majority of the boys are located in the most volatile Zones 1 and 2. Only one Zone 6 boy had a very close relationship and this is because his uncle is an activist. One Zone 4 boy said that he was taught by a political activist how to pretend to be a member of the popular party, though he and his entire family were members of the opposing party.

The second observation is that the closer boys lived to the garrison headquarters the more violent their behavioural history. Of the 53 boys, 15 had a history of consistent violent behaviour. Of these aggressive boys, 14 (87 per cent) lived within the most volatile zones ( 1 and 2, or the headquarters and the heart of the garrison). One lived in an enclave, and only one on the periphery of the garrison. Eight of the 53 boys were categorised as moderately aggressive. Five (63 per cent) of the
Figure 1 Relationship between boys' proximity to political gang headquarters and their levels of aggression

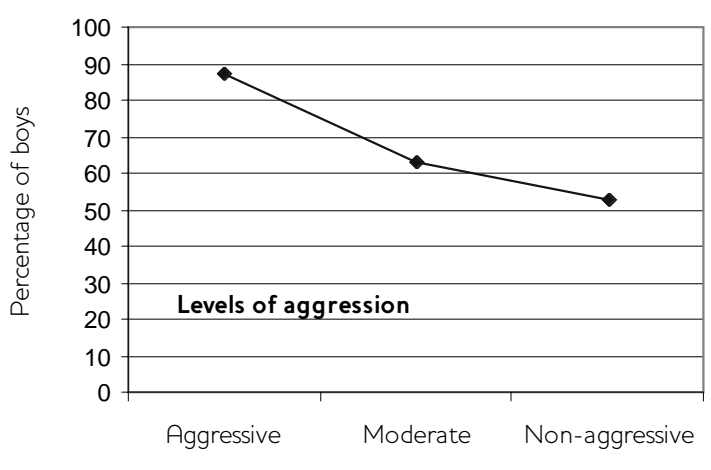

eight lived within the most violent zones. Just about a half ( 53 per cent) of the 30 nonaggressive boys lived in these very volatile zones. The results displayed in Figure 1 show a direct relationship between where a boy lives and his propensity to violence.

The third observation is that boys are deliberately trained by politicians (MP and councillor), political activists and some community and family members to fear, hate and harm people who support the opposing political party. Only eight ( 15 per cent) of the 53 boys said they did not fear supporters of the opposing political party. Three of these boys were from the nonaggressive group. One boy observed that it was the opponents who were being attacked and consequently dismissed the socialisation to fear and hate political rivals. Instead he had developed a dislike for the MP, the councillor and all who taught tribal politics and hatred. 'I hate my party, they too violent,' he said. The 20th boy of the non-aggressive group (NA20) said that he was a Christian and had not learnt to fear or hate anyone. The 28th boy (NA28) of the group stated that where he lived (near-poor or Zone 6) people did not hate or fear each other. Five from the group of aggressive boys claimed they did not fear supporters of the opposing political party for varying reasons. Three did not fear them because the opponents were the usual victims in the feud. One no longer feared them as the Boss (drug don) of his community had developed a drug business with other dons of the opposing political party. The final boy, one with special learning needs, claimed he loved everybody, even the ones he attacked. It is important to note that the "no fear of them for they are the victims' came from 
boys who reside in the headquarters or heart of the garrison (Zones 1 and 2).

The majority (85 per cent) of the boys fear people of the opposing political party and see them as threat to life and livelihood. The boys said that they learnt to fear the people of the opposing political parties from adults around them but also from their own experiences. The following are some of the thoughts expressed:

We see them go through our communities in gangs, armed with guns.

The enemies are bad and always want to hurt us.

\section{They cut people throat.}

Their leader wants to kill us and our leader, and [so] they cannot be trusted.

They are old bangarang! [problems].

Any side lose election, their don has no food to give away [threat to food security].

Their leader wants to make life hard for us. If they win even bag juice going to go up [price increase].

\subsection{Hatred of and harm to political opponents}

The hatred we observed was immense, including hints of children participating in murders or wishing to do so. What was saddest was that three of the boys reported that politicians told them to hate their opponents. One boy explained that he remembered well because the politician was dressed up as Santa Claus at the Christmas party when he told him to not 'come in di community'. (Though the reference is made to suggest that the MP was speaking about disallowing gays from entering the community it is common for persons in Jamaica to refer to any rival in this context.) Equally strange is the fact that this Santa Claus wore party colours as he distributed food and toys to the children. The boy pointed out that neither the JLP nor the PNP had the full colours of Santa Claus and he was not stupid: one has white but no red and the other one has orange (which is close to red) but no white, 'so him not fooling me ... and me not killing nobody for them'. Another boy reported that the politician told him that if their party was not in power they would go hungry, so he must be prepared to defend the party 'to the end'. The use of the word end could be interpreted as having implications for violence against self or others. The third boy said his political representative told a group of boys that the policy of the community was: 'Walk and live as a [party supporter] or die as a batty man [opponent].'

The other boys claimed they learned from community political activists and family members, especially from mother and father, to hate people of the opposing party. Eighteen of the boys expressed extreme anger and hatred for persons of the opposing political party. Eight (44 per cent) of these extreme haters came from the aggressive group. These conclusions are drawn from the words of the boys, as well as their facial expressions and actions towards the puppet representing the opposing party. The most frightening ones are as follows:

I want a gun to shoot hop fence [hop fence people are those who change their political conviction].

One boy almost destroyed the puppet that represented the opposing political party: $M i$ would get mad ... rrrr [growls like a dog] dog bite up people.

My people dem kill [opponents] and I don't feel bad bout it. Like to see dem dead.

Dem dead; we kill dem.

Saw them beat someone and they killed my best friend; they broke my heart.

We get matches and burn down dem house.

We call the Boss to kill them.

Would be brutal, me kill him cause him bad [choking the puppet].

Less than a third of the boys considered people of the opposing political party their friends or creations of God or could find reasons to share their food or toys with them. The aggressive boys (including the moderates) were the most likely to hate and express a wish to harm others. Consequently, they were the least likely to express a wish to share with a boy from the opposing political party. Only four of the 23 (17 per cent) aggressive and moderately aggressive boys said they would share with those considered by their communities as enemies. 
Figure 2 Comparison of garrison boys with those of primary and preparatory regarding political socialisation

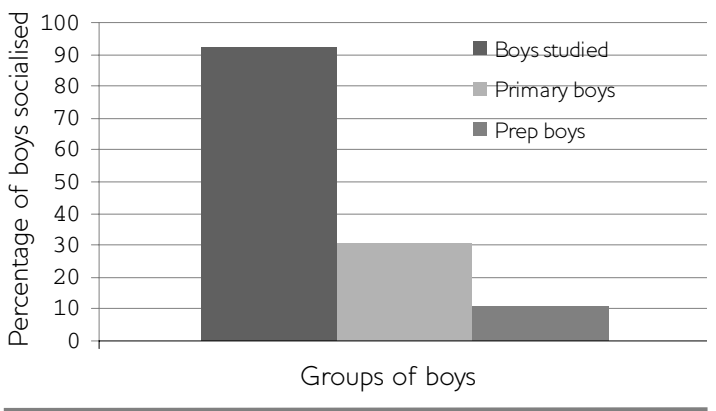

The fourth observation is that irrespective of proximity to the headquarters of a garrison all boys (with few exceptions) living in or close to a garrison are forced to be politically socialised at least to some extent. Only four of the 53 boys did not immediately recognise the political meaning of the colours orange (PNP) and green (JLP). One child had severe learning challenges and the other three were from Christian homes situated on the periphery - hence having double sources of shielding. So worrying was this data that the team set up two control groups in grade one classes in a non-garrison primary school with children of mixed socioeconomic backgrounds (working to middle classes) and in a preparatory school comprising children of upper classes in order to assess the extent to which the socialisation of such high levels of tribal politics was commonplace in Jamaica. The results are displayed in Figure 2. Forty-nine (92 per cent) of the boys studied identified immediately that the orange and green puppets represented the PNP and the JLP and made negative statements about the opposing party. This was compared to five (31 per cent) of the 16 boys from the primary school and one (11 per cent) of the nine boys from the preparatory school. What is even more interesting is that all five of the boys from the primary school who made an immediate connection between the colours and politics came from garrisons. The lone boy from the preparatory school who declared that he did not like one of the colours for political reasons is the son of a political activist. The comparative data show that boys who live in garrison communities are robbed of their childhood. They are trapped in violence and lost to the wishes of manipulating politicians and drug dons, further reinforced by some parents and neighbours. This picture is undeniable when they are compared to non-garrison boys of the same age.
When the boys were asked to select their hero and role model, their responses were also clearly distinguished from those of the boys from the primary and preparatory schools. Of the 53 boys, 20 (38 per cent) selected either the current leader of their political party (Bruce Golding of the JLP or Portia Simpson-Miller of the PNP) or the founder of their political party (Alexander Bustamante of the JLP or Norman Manley of the PNP) as their hero. The founders of their political party was described as the 'real big man' while the founder of the opposing political party was described as gay. Most of the boys claimed they got their information from the politicians, activists, parents and neighbours. When the boys of the control groups were asked to name their heroes, Marcus Garvey (8 of 25), Jamaica's most popular hero, was the prime candidate. He was rated highly for his contribution to black pride internationally and nationally. For the boys who live in the garrison Marcus Garvey was the second choice, as the first position was reserved for their political leaders.

\section{In closing}

A boy's life is largely determined by the environment in which he is raised. Sadly, the agency of political tribal socialisation is so strongly set that a large proportion of the garrison seems to be involved in preparing these boys for turf war, equipping them with fear of others and enough hatred to maim others. So violent are some communities and so aggressive their training to create little hardened political gangsters that many of the boys expressed that they were safest at school. The most positive influence found were teachers, pastors, Christian mothers and some fathers who stated that they were willing to die in the process of shielding their sons from the dangers of the garrison. Politicians and dons were found to be the most active agents in preparing the infant boys for community political tribal war.

Over 200,000 people of the KMR live in extreme violence and this will not change unless the executive of both political parties make the decision to change the present political divide, or civil society and international development agencies apply some degree of force to persuade them to seek alternative means of securing the votes of the urban poor.

There is urgent need for the construction of watchdog groups to protect Jamaican children. 
The rights of children remain a foreign concept to many adults in Jamaica. In 2007, over 700 children went missing. In 2008, the situation worsened dramatically. In the first nine months of 2008 , over 700 children went missing in Jamaica, 68 of them confirmed dead (Sunday Gleaner, 5 October 2008). The formation of protective state structures in the region is in a stage of infancy. Only after years of appeals by local and international children's rights groups, did the Jamaican Government establish the Child Care and Protection Act (2004) and set up an office of Children's Advocate to enforce the protection of children. Nonetheless, the office does not have the powers and capacity to address the abuse of children by political and other agents. In a World Bank-sponsored study carried out by Herbert Gayle and Horace Levy (2007), adolescents illustrated that only the schools in Jamaica functioned as social service providers. Police officers, politicians and many parents and community leaders sought to abuse children rather than provide for them and protect them as stipulated by the Rights of the Child.

In Jamaica, communities will have to improve their reach to boys. Unfortunately, the support system in the community, while it helps to protect and nurture the boys, also exposes them to political tribalism and violence. The churches are playing a tremendous role. At this age, the church has more influence in the boys' lives than later when they become adolescents. It seems that an innovation such as a care centre might help to rescue some of these boys. These are centres where children can go after school to do their homework and play and experience love and care. These centres or programmes can be hosted in churches, community centres or schools. They can be funded by civil society, government and churches. Communities that have already established homework centres can simply expand their programmes to include the care of the younger children. The essence of these centres is simply to extend the period of love and care children, especially boys, receive from school while shortening the period of time they spend experiencing violence and hardship in their communities.
The most critical ingredient missing from the development plans in Jamaica is a well-developed welfare system that focuses on the most vulnerable children and their households, run by social workers independent of party politics. At present, less than 10 per cent of Jamaica's population is covered by the state's meagre welfare system known as PATH. There needs to be a graduation of the programme's cover by 1 per cent per year or every two years until all below the poverty line (below 20 per cent) are covered. All households below the poverty line need to benefit from full state-supported education at least up to secondary school level. It should be designed to support all students found to be 'needy' or those forced to engage in economic activities at the expense of attending school; or those households where parents are encouraged to participate in political feuding in order to get assistance. Needy children and their households should be selected based on the recommendation of guidance counsellors and/or schools' needs-assessment programmes. At present, it is the MPs and the drug dons of garrison communities who form the core of the 'real welfare'. This allows them to control the households and train the boys for the continuance of the tribal political system. In fact each year the government budgets money to give to MPs to keep this machine of dependence going in the garrisons - rather than facilitate the gradual development of the present struggling welfare system. The result is that in many communities up to 40 per cent of the boys are out of school (see Gayle 2004 et al. and ILO/Children First 2001). The situation becomes even worse for boys of political garrisons if the political party their communities support does not form the government, thus motivating them to assist politicians to remain in power or to win parliamentary seats and form the government. In summary, Jamaica's greatest asset is its children, but service providers, especially the state, must be prepared to change the system that harms them to one that provides the opportunity structures that will foster positive agency. 


\section{Notes}

1 This article is part of a larger report (Gayle 2008).

2 This is a term used by Town Planning to describe the country's most urban belt. It comprises Kingston, urban St Andrew, Spanish Town and parts of the St Catherine South Police Division including the

\section{References}

Amnesty International (2001) 'Jamaica: Amnesty International to send observer to Commission of Inquiry into the July violence in West Kingston', 5 October, AI Index AMR 38/023/2001 - News Service Nr 177, www.amnesty.org/en/library/asset/AMR38/ 023/2001/en/dom-AMR380232001 en.html (accessed 26 October 2008)

Brown, Janet and Chevannes, Barry (1998) Why Man Stay So: An Examination of Gender Socialization in the Caribbean, Kingston: University of the West Indies

Chevannes, Barry (2001) Learning to Be a Man: Culture, Socialization and Gender Identity in Five Caribbean Communities, Kingston: University of The West Indies Press

Chevannes, Barry (1999) What We Sow and What We Reap: Problems in the Cultivation of Male Identity in Jamaica, Grace Kennedy Foundation Lecture, Kingston: Grace Kennedy Foundation

Chevannes, Barry and Gayle, Herbert (1998) Solid Waste Management: Profiles of Inner City Communities in the Kingston Metropolitan Area, Kingston: Faculty of Social Sciences, University of the West Indies

Erikson, Erik (1968) Identity, Youth and Crisis, New York: Norton

Evans, Hyacinth (1999) Gender and Achievement in Secondary Education in Jamaica, Working Paper 2, Kingston: Planning Institute of Jamaica Evans, Hyacinth and Davies, Rose (1997) 'Overview of Issues in Childhood Socialization in the Caribbean', in Jaipaul L. Roopnarine and Janet Brown (eds), Caribbean Families: Diversity Among Ethic Groups, Westport: Ablex

Gayle, H. (2008) 'Young Birds that Know Storm: Life Experiences of Boys of Ages 6-8 Years Living in Communities of Extreme Poverty and Violence', draft report, unpublished, Kingston: University of the West Indies
Metropolitan of Portmore. It has a population of over one million.

3 These views are also shared by political scientist Carl Stone, especially in his 1980 and 1985 works.

4 See the work of political anthropologists Swartz et al. (1966) and Nicolas (1966).

5 The MICS 2005 comprised 4,767 households.

Gayle, H. and Levy, H. (2007) 'Forced Ripe: How Youth of Three Selected Working Class Communities Assess their Identity, Support, and Authority Systems, Including their Relationship with the Jamaican Police', draft report, unpublished, Kingston: University of the West Indies at Mona

Gayle, Herbert; Grant, A.; Bryan, P.; Yee-Shui, M. and Taylor, C. (2004) The Adolescents of St. Catherine: A Study of their Survivability and Reproductive Health, Spanish Town: Children First Agency

ILO/Children First (2001) 'Baseline Survey in Child Labour: Spanish Town', unpublished report, Spanish Town

Manning, Gareth (2008) 'Less Care of Boys', Daily Gleaner, 24 February 2008

Mills, Gladstone (1997) Westminster Style Democracy: The Jamaican Experience, Grace Kennedy Foundation Lecture, Kingston: Grace Kennedy Foundation

Ministry of Health (2002) Multi-source for Determining Mortality in Jamaica, Kingston: Ministry of Health

Ministry of National Security (1997) Report of the National Committee on Political Tribalism, Kingston: Ministry of National Security Nicolas, Ralph (1966) 'Segmentary Factional Political Systems', in M. Swartz, V. Turner and A. Tuden (eds), Political Anthropology, Chicago: Aldine Publishing Company

Stone, Carl (1985) Class, State and Democracy in Jamaica, Kingston: Blackett Publishers

Stone, Carl (1980) Democracy and Clientelism in Jamaica, New Brunswick: Transaction Books

Swartz, Marc; Turner, V. and Tuden, A. (1966)

Political Anthropology, Chicago: Aldine Publishing Company

UNICEF and STATIN (Statistical Institute of Jamaica) (2007) Multi-indicator Cluster Survey 2005, Kingston: UNICEF and STATIN 